\title{
NOTICE TO AUTHORS
}

American Antiquity publishes original papers on the archaeology of the New World and on archaeological method, theory, and practice worldwide. Authors of papers on Latin American topics are encouraged to submit their work to Latin American Antiquity. Papers on Latin American archaeology addressing broad methodological, theoretical, or comparative issues may be accepted by either journal after consultation with the editors. Authors submit manuscripts to the editor for consideration as ARTICLES, REPORTS, COMMENTS, or FORUM essays. REVIEWS and BOOK NOTES are solicited by the respective associate editor. OBITUARIES should be submitted to the editor, The SAA Archaeological Record, for publication (see SAA Bulletin March/April 1996, p. 7, for further details).

Authors are required to submit manuscripts electronically through Editorial Manager ${ }^{\odot}$ (http://www.editorialmanager/aq). Detailed information on policy, style, and technical matters of manuscript preparation is given in the "Editorial Policy, Information for Authors, and Style Guide for American Antiquity, Latin American Antiquity, and Advances in Archaeological Practice," which can be accessed at http://www.saa.org/AbouttheSociety/Publications/StyleGuide/tabid/984/Default.aspx.

The editor reserves the right to evaluate manuscripts (with or without peer review) for appropriate subject matter, quality, length, and compliance with the style guide. Manuscripts may be returned to authors if they fail to meet expectations or conform to these guidelines. Manuscripts are evaluated by the editor in consultation with peer referees, as appropriate. The editor has the final responsibility for all decisions regarding manuscripts. The review process generally takes a minimum of two to four months. Authors will be notified as soon as a decision is reached to accept (outright or with revisions) or reject a manuscript.

\section{BOARD OF DIRECTORS OF THE SOCIETY FOR AMERICAN ARCHAEOLOGY}

\section{Officers}

President: SUSAN M. CHANDLER, RPA, Alpine Archaeological Consultants Inc., Montrose, CO 81401 President-elect: JOE E. WATKINS, PhD, RPA, Takoma Park, MD 20912

Secretary: EMILY S. MCCLUNG DE TAPIA, PhD, RPA, Inst de Investigaciones

Antropológicas UNAM/CU Circuito Exterior S/N, Ciudad Universitaria, Copilco-Coyoacan, Mexico DF, DIF 04510, Mexico

Secretary-elect: TERESITA MAJEWSKI, RPA, Statistical Research, Inc., Tucson, AZ 85712

Treasurer: RICKY R. LIGHTFOOT, RPA, Mancos, CO, 81328

\section{Board Members at-Large}

JANE EVA BAXTER, DePaul University, Deptartment of Anthropology, 2343 North Racine, Chicago, IL 60614-2458

LUIS JAIME CASTILLO BUTTERS, PhD, Pontificia Univ Catolica Del Peru, Av Universitaria 1801, San Miguel, Lima, 1 Peru

JOHN G. DOUGLASS, RPA, Statistical Research, Inc., PO Box 31865, Tucson, AZ 85751

PATRICIA GARCIA-PLOTKIN, Agua Caliente Band of Cahuilla Indians, Palm Springs, CA 92264

HEATHER A. LAPHAM, PhD, UNC Chapel Hill, Chapel Hill, NC 27599-3120

LYNNE P. SULLIVAN, PhD, RPA, University of Tennessee, Knoxville, TN 37917

STEVE A. TOMKA, Raba Kistner Environmental, Inc., San Antonio, TX 78249

\section{Ex-Officio Board Member}

TOBI A. BRIMSEK, Executive Director, Society for American Archaeology, 1111 14th Street NW, Suite 800, Washington, DC 20005 


\section{FORUM}

367 Why Do Fewer Women Than Men Apply for Grants After Their PhDs?

Lynne Goldstein, Barbara J. Mills, Sarah Herr, Jo Ellen Burkholder, Leslie Aiello, and Christopher Thornton

\section{ARTICLES}

387 Drinking Performance and Politics in Pueblo Bonito, Chaco Canyon

Patricia L. Crown

407 The Archaeology of Home: Qiaoxiang and Nonstate Actors in the Archaeology of the Chinese Diaspora Barbara L. Voss, J. Ryan Kennedy, Jinhua (Selia) Tan, and Laura W. Ng

427 The Study of Sustained Colonialism: An Example from the Kashaya Pomo Homeland in Northern California Kent G. Lightfoot and Sara L. Gonzalez

444 Modeling Relationships between Space, Movement, and Lithic Geometric Attributes Benjamin Davies, Simon J. Holdaway, and Patricia C. Fanning

462 Coupling Lithic Sourcing with Least Cost Path Analysis to Model Paleoindian Pathways in Northeastern North America

Jonathan C. Lothrop, Adrian L. Burke, Susan Winchell-Sweeney, and Gilles Gauthier

\section{REPORTS}

485 Further Insights into Paleoindian Use of the Powars II Red Ocher Quarry (48PL330), Wyoming George C. Frison, George M. Zeimens, Spencer R. Pelton, Danny N. Walker, Dennis J. Stanford, and Marcel Kornfeld

505 Three Generations under One Roof? Bayesian Modeling of Radiocarbon Data from Nunalleq, Yukon-Kuskokwim Delta, Alaska

Paul M. Ledger, Véronique Forbes, Edouard Masson-Maclean, Charlotta Hillerdal, W. Derek Hamilton, Ellen McManus-Fry, Ana Jorge, Kate Britton, and Richard A. Knecht

525 Late Dorset Triangular Midpassages in the Canadian Arctic and Northwest Greenland: Origins and Dispersal

John Darwent, James M. Savelle, Christyann M. Darwent, Arthur S. Dyke, Hans Lange, Genevieve M. LeMoine, and Claude Pinard

536 The Manufacture and Burial of Hohokam Disk Beads in the Tucson Basin Jenny L. Adams and Mary F. Ownby

552 Growth of a Village: Using Fluoride Analysis and Artifact Frequencies to Examine Early Fort Ancient/ Mississippian Household and Site Formation

Robert A. Cook and Mark R. Schurr

On the Cover: Clovis points recovered during salvage excavations between 2014 and 2016. Catalog numbers noted. From "Further Insights into Paleoindian Use of the Powars II Red Ocher Quarry (48PL330), Wyoming," George C. Frison and colleagues, p. 490.

(2) The paper used in this publication meets the requirements of ANSI/NISO Z39.48-1992

(Permanence of Paper).

\section{Cambridge Core}

For further information about this journal 